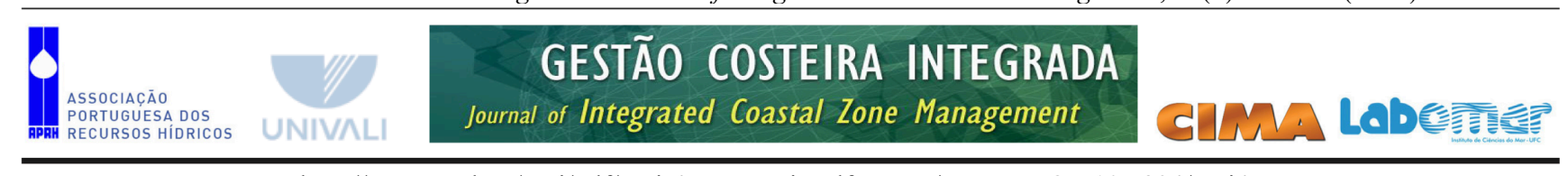

http://www.aprh.pt/rgci/pdf/rgci-455_Morais.pdf

DOI: $10.5894 /$ rgci455

\title{
PSR framework applied to the coastal management of "Complexo Estuarino-Lagunar Iguape-Cananéia" - CELIC (São Paulo, Brazil), in terms of sanitation and public health ${ }^{*}$
}

\author{
Lucas G. Morais $^{\circledR}{ }^{a}$; Denis M. S. Abessa ${ }^{a}$
}

\begin{abstract}
The Coastal Zone (CZ) is of great importance in maintaining natural resources and life. This region presents multiple anthropic activities of economic, social and environmental interest, which can be potentially harmful to natural ecosystems. Furthermore, it is estimated that one third of the world's population inhabits the CZ. In Brazil, neither the intensification of CZ activities nor population growth have frequently been followed by the implementation of the basic infrastructure required, which has caused the $\mathrm{CZ}$ to become an area with conflicts of interest and uses. In this study, the Complexo Estuarino-Lagunar Iguape-Cananéia (CELIC) region was chosen for an analysis of basic sanitary conditions, because it presents a profile that is unique along the São Paulo coast. This region was chosen in an attempt to understand whether it is managed in a way that promotes both quality of life and a healthy environment. To achieve that, information on different indicators involving sanitation, the healthcare system, the population, the economy and the environment were collected from public databases and the pressure-state-response (PSR) framework was used to integrate all of the collected information. The study presents relatively mild pressures when compared to other coastal regions from the state of São Paulo, although in CELIC, pressures present an increasing pattern. Status indicators show that there are structural deficiencies in terms of basic needs, such as health and sanitation. Government responses, however, have not addressed these problems, especially the health issues. Though the local economy has evolved consistently, the current status of sanitation and health structures reveals failings in these services, a situation which shows that economic gains did not effectively result in improvements to these structures. Thus, despite favorable conditions (low population size, the presence of protected areas, and the concentration of the population in urban areas), which should facilitate the planning and management of the aforementioned institutions, the pressure seems to keep increasing. It has resulted in a scenario in which the lack of infrastructure for healthcare and sanitation stand out and there seems to be a lack of political initiative toward actions that aim to mitigate or resolve the problems.
\end{abstract}

Key-words: coastal management, Estuarino-Lagunar Iguape-Cananéia, basic sanitation.

\section{RESUMO}

Modelo PSR aplicado na gestão costeira do “Complexo Estuarino-Lagunar Iguape-Cananéia” - CELIC (São Paulo, Brasil), em termos de saneamento e saúde pública

A zona costeira (ZC) é uma região de características únicas e de grande relevância à manutenção dos recursos e da vida, e que representa um local onde se desenvolvem diversas atividades de grande interesse econômico, social e ambiental. $O$ crescimento populacional e a intensificação das atividades desenvolvidas na ZC brasileira geralmente não são acompanhados pela instalação das infraestruturas básicas necessárias, transformando essa região em um cenário de conflitos de interesses e usos. No estado de São Paulo o Plano Estadual de Gerenciamento Costeiro (PEGC) divide a ZC paulista em: Litoral Norte, Baixada Santista, Complexo Estuarino-Lagunar de Iguape-Cananeia (CELIC) e Vale do Ribeira. No presente estudo escolheu-se a região do CELIC para análise das condições de saneamento básico, por apresentar um perfil diferente do restante do litoral paulista; e com a finalidade de compreender se nessa região do litoral existe uma gestão que efetivamente

\footnotetext{
(a) Corresponding author to whom correspondence should be addressed. e-mail: <morais.biologia@yahoo.com.br>

a Universidade Estadual Paulista "Julio de Mesquita Filho" - Campus Experimental do Litoral Paulista, Parque Bitarú, Praça Infante Dom Henrique S/N, CEP: 11330-900, São Vicente- SP, Brasil.
}

* Submission: 21 NOV 2013; Peer review: 18 JAN 2014; Revised: 28 FEB 2014; Accepted: 29 MAY 2013; Available on-line: 23 JUN 2014 
promova a qualidade de vida e ambiental. Para isso foram coletados índices disponíveis em bases de dados públicas e utilizou-se o modelo pressão - estado - resposta (PER) com o intuito promover a integração das informações. A região estudada encontra-se numa situação onde as pressões são relativamente brandas ao comparadas com as demais regiões litorâneas do estado de São Paulo, porém com um comportamento crescente. Os indicadores de estado demonstram que há uma carência estrutural referente a aspectos básicos como: saúde e saneamento básico. Por sua vez não são evidenciadas respostas que atendam a essas carências, principalmente no que diz respeito à saúde. Mesmo que os aspectos econômicos na região tenham evoluído bastante, o atual estado das estruturas de saúde e saneamento reflete uma precariedade desses serviços, que por sua vez revelam que os ganhos econômicos obtidos não foram revertidos, pelo poder público, de maneira eficaz visando à melhora dessas estruturas. O que se pode observar é que apesar das condições - baixa população, presença de áreas protegidas e a concentração da população na área urbana - o que teoricamente facilitaria o planejamento e a gestão dos aspectos aqui abordados, as pressões parecem aumentar ao longo do tempo, repercutindo em um estado em que se destaca a falta de infraestrutura de saneamento e saúde, que não é acompanhada de ações que procurem mitigar ou resolver esse cenário.

Palavras-chave: gerenciamento costeiro, Complexo Estuarino-Lagunar Iguape-Cananéia, saneamento básico.

\section{Introduction}

About one third of the world's population lives on or close to the coastal zone (CZ), which puts intense pressure on ecosystems and represents a challenge for spatial planning (UNEP, 2006). The CZ is usually characterized as a region where several anthropic and economic activities take place; thus these regions are of high economic, social and environmental importance. Furthermore, major urban centers, industries, ports, marinas, and aquaculture, among other anthropic activities and structures, tend to be concentrated around the $\mathrm{CZ}$. This region is continually experiencing growing tourism demands and intense real estate speculation, particularly in Brazil (Jablonski \& Filet 2008).

The Brazilian CZ is approximately $8500 \mathrm{~km}$ long and covers 17 states (Federal Law $n^{0}$ 7.661/88). This region is inhabited by $25 \%-35 \%$ of the country's population (Moraes, 2007; Scherer et al., 2009); the exact percentage depends on the definition of the CZ. Moreover, economic activities performed in the $\mathrm{CZ}$ correspond to approximately $70 \%$ of gross domestic product (GDP) (Freitas, 2005), a number which reflects the importance of these areas to the country. In addition, over the last few decades, the $\mathrm{CZ}$ has experienced an intensification of economic activities combined with accelerated population growth and economic development, which have rarely been followed by the proper allocation of space and the installation of the required infrastructure. Thus, throughout Brazil's history, the country's CZ has been the backdrop for many conflicts of interest and uses that need to be solved through the use of different strategies. One strategy includes coastal management plans at different levels of administration, which play an important role since they can be implemented at various levels.

The Brazilian Coastal Zone Management Plan (CZMP) includes several interconnected topics related to the promotion of sustainability in the CZ. These topics are aimed toward monitoring, controlling and maintaining environmental quality, and also toward addressing criti cal issues such as urbanization, the occupation and use of lands, the use of mineral resources and waters, urban mobility, the production and distribution of energy, and also tourism, housing, sanitation, public healthcare and environmental conservation. Sanitation is one of the most important issues involved in sustainability, because it is involves both public healthcare and impacts on natural ecosystems (IBGE, 2008). Therefore, the variables related to this particular topic represent key aspects for $\mathrm{CZ}$ management, as well as for the appropriate diagnosis for a determined region, and they may subsidize relevant future decision making.

The Brazilian CZMP strongly supports the decentralization of management efforts, because it offers a structure composed of state and municipal CZMPs in order to provide different types of governance at local, regional and federal levels. Despite the slowness in the implementation of actions to improve coastal management, these plans represent an advance in terms of CZ planning, especially because they stimulate integration among different sectors of society, an objective which had not been achieved by previous forms of managing $\mathrm{CZ}$. These characteristics are fundamental in the development of Integrated Coastal Zone Management (ICZM), which is a multi-faceted process that seeks to overcome the fragmentation inherent in the sectorial management approach and to enable multiple uses of coastal and marine resources by different sectors of society in a sustainable way by taking the different scenarios present in the $\mathrm{CZ}$ into account (Cicin-Sain \& Knecht, 1998).

In light of this information, the state of São Paulo established its State CZMP (State Law n ${ }^{\circ}$ 10.019/98), which divided the $\mathrm{CZ}$ into four administrative sectors: North Coast, Central Coast (known as the Baixada Santista), South Coast (or the Complexo Estuarino-Lagunar Cananéia-Iguape - CELIC) and the Ribeira de Iguape River Valley. Among the São Paulo coastal regions, the CELIC presents a unique profile when compared to the central and northern regions, particularly because it is 
known for its natural conservation features (it is comprised of the important Atlantic rainforest and estuarine areas, which make up a biosphere reserve and relevant wetland sites according to the Ramsar Convention). In addition, the CELIC is characterized by low population density, a lack of large-scale economic activities, the presence of a wide set of terrestrial and aquatic protected areas, despite its proximity to major urban and industrial centers such as the Baixada Santista Metropolitan Region, the São Paulo Metropolitan Region and the Curitiba Metropolitan Region. Moreover, there are few studies on the CELIC to support the CZMP in this region, despite its ecological importance.

The goal of this investigation was to evaluate the status of the conditions and management of the CELIC in terms of the region's water resources and sanitation in order to understand whether the management is being effective in promoting both environmental quality and the quality of life in the region. To achieve this, the Pressure- State-Response (PSR) framework was applied to the CELIC. This approach was developed in 1993 by the Organization for Economic Cooperation and Development (OECD), and it is based on the concept of causality; in other words, human activities exert pressures on the environment (Pressure), which, in turn, may exhibit altered quality and/or availability of natural resources (State), and the society usually responds to these changes through policies and/or economic, environmental and governmental actions (Response) (OECD, 1993). Methodological procedures of this nature have been rarely or under-used in Brasil (Carvalho \& Barcellos, 2009; Chaves \& Alipaz, 2007; Marotta et al., 2008), despite the relevance of results that this approach may provide for the coastal management.

\section{Material and Methods}

\subsection{Study area}

The CELIC is located on the south coast of São Paulo state (Figure 1) and includes the cities of Iguape, Cananéia and Ilha Comprida, as well as their respective non-urbanized areas. According to the SEADE Foundation, this region corresponds to $3409.30 \mathrm{~km}^{2}$ and has a population of 50,477 , which presents a significant set of environmental and landscape attributes that are reflected in the large number of protected areas.

\subsection{Collection and interpretation of data}

Temporal series data were collected from public databases on the websites of the SEADE Foundation, IBGE, CVE and environmental reports issued by the CETESB. In this study, the following pressure indicators were obtained and evaluated: Gross Domestic Product (GDP)

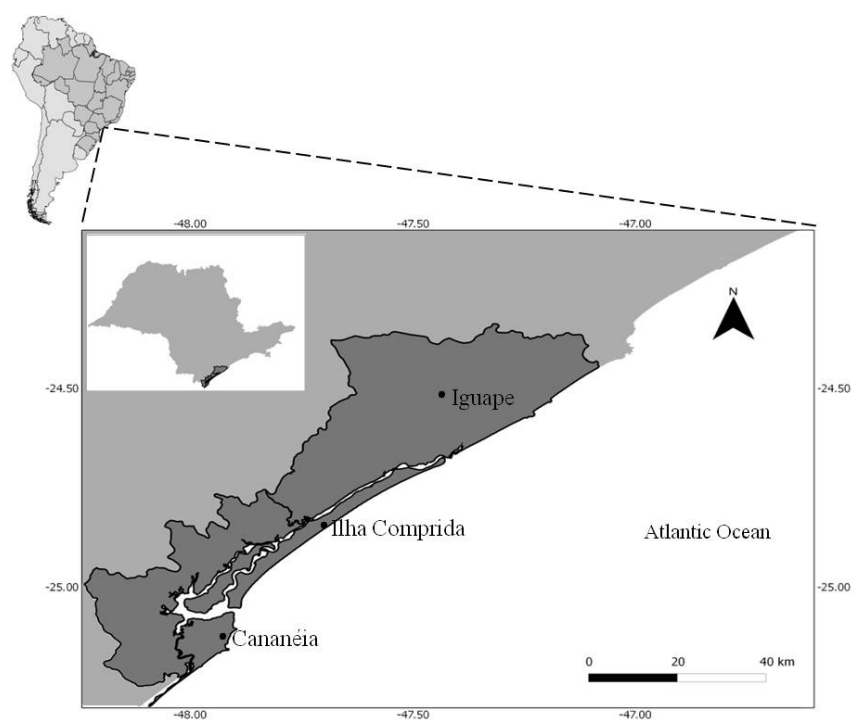

Figure 1 - Map of CELIC and the cities included in this region.

Figura 1 - Mapa da CELIC com as cidades incluídas nesta região.

of the municipalities of CELIC; resident population; population density; and urbanization rate. We highlight that in Brazil, the GDP for states, municipalities and regions have been calculated by the governmental agencies and are available at their official websites. The collected status indicators were the index of urban landfill quality; the beach bathing quality; the proportion of wastewater collected in relation to the total wastewater generated; the reduction ratio of domestic organic pollutant load; the number of cases of diarrhea; and the child mortality rate. Finally, the response indicators were the number of health professionals; the coefficient of hospital beds from the Brazil's public healthcare system (named "Sistema Único de Saúde - SUS", or Unified Health System) per thousand residents; and the percentage of households reached by water supply and sewage collection services.

First of all, the data were plotted and organized into graphs or tables in order to observe trend curves and / or make comparisons to national or state standards. Information had been collected since 1993 whenever possible; however, for many variables, the available data did not include every year between 1993 and 2013. Furthermore, the PSR framework was applied in order to organize the data according to its characteristics, interactions, and effects on the environment and society, as indicated in the OECD (1993).

The data were organized according to the PSR framework as shown in Figure 2. This framework employs the concept of cause and effect, and takes the flow of information and the recognition of societal responses into account for data integration. 


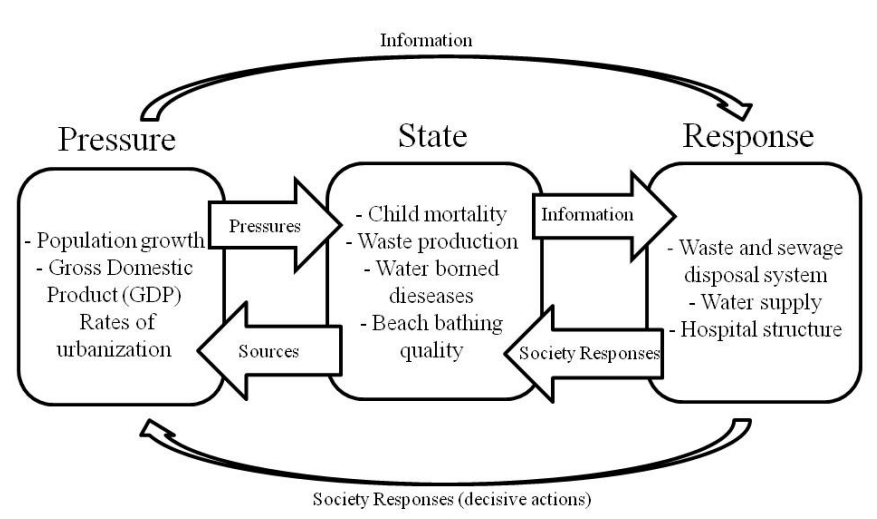

Figure 2 - PSR framework applied to coastal management sector of CELIC, in terms of sanitation and public health.

Figura 2 - PSR framework applied to coastal management sector of CELIC, in terms of sanitation and public health.

\section{Results and Discussion}

\subsection{Pressure}

The cities of Cananéia and Iguape experienced relatively low population growth in the period sampled (1993-2011), but in the last decade, Cananéia presented a decline in its population and Ilha Comprida presented a more pronounced population growth (Figure 3 ). However, it must be highlighted that these three cities all possess low populations. Urbanization rates observed are high in the three cities (Table 1), and reach up to $100 \%$ in Ilha Comprida. These factors indicate that the population of the three cities is largely concentrated in urban areas. Population growth, urbanization and economic demands in coastal regions have been indicated as some of the main vectors of pressure, either by increasing the demand for natural resources or by promoting the loss of habitats and landscapes (UNEP, 2006).

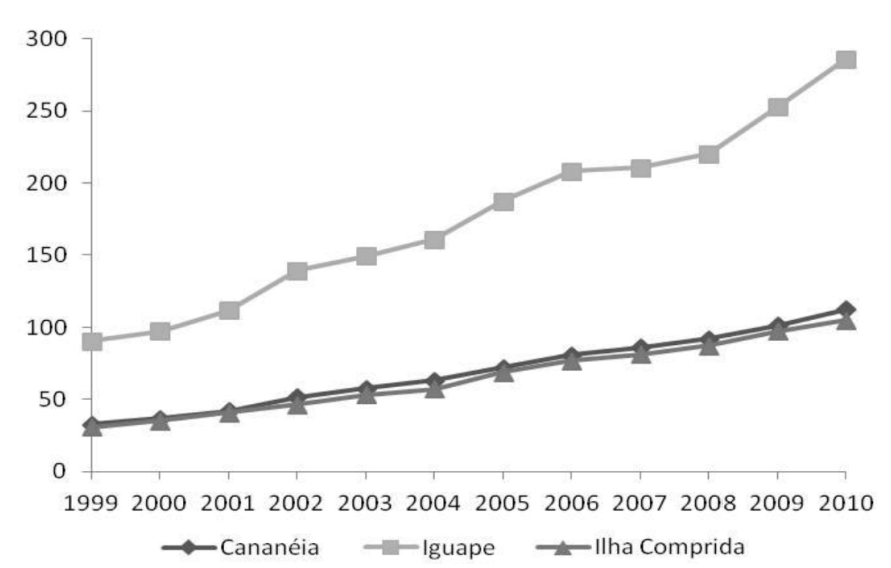

Figure 3 - Population growth in CELIC cities (Source: SEADE Foundation).

Figura 3 - Population growth in CELIC cities (Source: SEADE Foundation).

Cananéia, Iguape and Ilha Comprida have low population densities (Table 1), and they possess the lowest values along the coast of São Paulo. They are also much lower than the average density observed for the state CZ (261.66 inhabitants $/ \mathrm{km}^{2}$ ). This situation is partly due to the fact that Iguape and Cananéia have the largest territorial areas of the São Paulo coast.

Because of their tourist attractions, the cities in the CELIC have a periodic seasonal variation in their population, and the population increases during the summer months. Thus, it would be useful to analyze the data of this temporal fluctuation for a better understanding of the population dynamics in this region; however, there are no official data available. Furthermore, according to the SIG-RB (2012), the study of fluctuating populations is important for planning the demands and needs for public services. Therefore, due to the unavailability of data, the present study focused only on the data on the resident population. For a global analysis, and considering the fact that the tourist season currently occurs only 1 to 2 months a year, the resident population data allows for a trend analysis and a reliable diagnosis.

Between 1999 and 2010, GDP has more than tripled in each of the cities; Iguape has presented the highest revenue (Figure 4). These increases follow state and national trends which, in turn, are a consequence of the relative stability and economic growth experienced by Brazil in recent years.

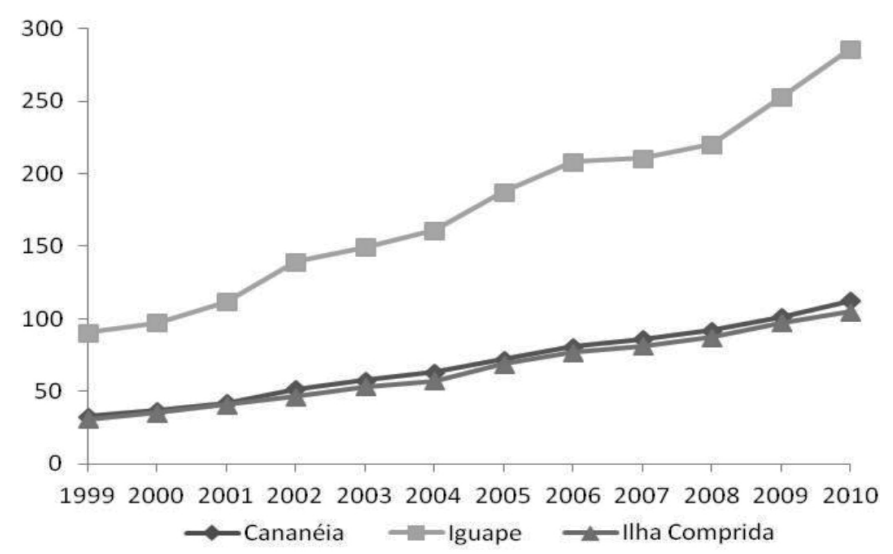

Figure 4 - Time series of the Gross Domestic Product of CELIC cities (Source: SEADE Foundation).

Figure 4 - Time series of the Gross Domestic Product of CELIC cities (Source: SEADE Foundation).

GDP provides a measure of the degree of economic activity in cities, and thus provides an estimate of the economic pressures induced by the population. However, GDP is an index largely used to measure market production (Stiglitz et al., 2009), and does not necessarily reflect a measure of population welfare, or quality of life and/or environment (Stiglitz et al., 2009; Cavalcanti, 2004). Tsalik \& Schiffrin (2005) pointed out that, over the last forty years, many places around the world have experienced an increase in GDP due to petroleum 
Table 1 - Time series data on land occupation in CELIC cities.

Tabela 1 - Time series data on land occupation in CELIC cities.

\begin{tabular}{lcccccc}
\hline \multirow{2}{*}{ Year } & \multicolumn{2}{c}{ Urbanization Rate (\%) } & \multicolumn{3}{c}{ Demographic Density hab/km $\mathbf{k}^{\mathbf{2}}$} \\
\cline { 2 - 7 } & Cananéia & Iguape & Ilha Comprida & Cananéia & Iguape & Ilha Comprida \\
$\mathbf{1 9 9 3}$ & 81,12 & 76,48 & & 8,03 & 13,14 & 19,95 \\
$\mathbf{1 9 9 4}$ & 78,93 & 75,33 & 100 & 8,29 & 13,24 & 22,15 \\
$\mathbf{1 9 9 5}$ & 79,62 & 75,99 & 100 & 8,56 & 13,35 & 24,34 \\
$\mathbf{1 9 9 6}$ & 80,27 & 76,65 & 100 & 8,82 & 13,45 & 26,53 \\
$\mathbf{1 9 9 7}$ & 80,88 & 77,32 & 100 & 9,08 & 13,54 & 28,71 \\
$\mathbf{1 9 9 8}$ & 81,43 & 77,98 & 100 & 9,34 & 13,63 & 30,9 \\
$\mathbf{1 9 9 9}$ & 81,97 & 78,64 & 100 & 9,61 & 13,72 & 33,1 \\
$\mathbf{2 0 0 0}$ & 82,49 & 79,31 & 100 & 9,88 & 13,84 & 35,29 \\
$\mathbf{2 0 0 1}$ & 82,97 & 79,97 & 100 & 9,9 & 13,97 & 36,51 \\
$\mathbf{2 0 0 2}$ & & & & 9,92 & 14,07 & 37,76 \\
$\mathbf{2 0 0 3}$ & & & & 9,91 & 14,16 & 39,01 \\
\hline $\mathbf{2 0 0 4}$ & & & & 9,88 & 14,25 & 40,21 \\
$\mathbf{2 0 0 5}$ & 85,25 & 80,99 & 100 & 9,88 & 14,33 & 41,43 \\
$\mathbf{2 0 0 6}$ & & & & 9,88 & 14,41 & 42,69 \\
\hline $\mathbf{2 0 0 7}$ & 82,88 & 79,97 & 100 & 9,89 & 14,47 & 43,97 \\
$\mathbf{2 0 0 8}$ & & & & 9,88 & 14,50 & 45,27 \\
\hline $\mathbf{2 0 0 9}$ & 82,97 & 79,97 & 100 & 9,86 & 14,54 & 46,52 \\
$\mathbf{2 0 1 0}$ & 85,36 & 85,6 & 100 & 9,84 & 14,55 & 47,75 \\
\hline $\mathbf{2 0 1 1}$ & & & & 9,84 & 14,63 & 49,22 \\
$\mathbf{2 0 1 2}$ & & & & 9,86 & 14,63 & 48,21 \\
\hline & & & & & \\
\hline
\end{tabular}

activities in the $\mathrm{CZ}$, but these same areas have seen a major deterioration in the indicators related to social, economic, and environmental aspects.

The evolution of demographic data does not follow the GDP trend, since the latter has grown at a more accelerated rate. In regions where there is an increase in the resident population, it is expected that there is also an increase in the consumption of natural resources, waste generation and exploration of new areas. However, the study area has experienced low population growth, including periods of population decline. In turn, the GDP has grown at a rapid rate and economic issues may play a crucial role in the intensity of resource use and consumption, and the generation of increased volumes of waste.

\subsection{State}

The urban landfills of the three cities were classified as inadequate (Table 2) for most of period evaluated, according to the Quality Index regarding urban landfills (CETESB, 2010), which considers locational, structural and operational characteristics of landfills. However, only in the last two years there was a relative improvement because solid wastes started to be disposed into better structured landfills located in other cities outside
Table 2 - Structural quality evaluation of urban landfills used by CIEC cities.

Table 2 - Structural quality evaluation of urban landfills used by CIEC cities.

\begin{tabular}{l|ccc} 
Year & \multicolumn{3}{c}{ Quality Index of Urban Landfills } \\
& Cananéia & Iguape & Ilha Comprida \\
$\mathbf{1 9 9 7}$ & 3 & 2,5 & 4,5 \\
$\mathbf{1 9 9 8}$ & 6 & 2,6 & 0,9 \\
$\mathbf{1 9 9 9}$ & 4,9 & 2,6 & 1,3 \\
$\mathbf{2 0 0 0}$ & 4,1 & 3 & 1,2 \\
$\mathbf{2 0 0 1}$ & 3,4 & 3,5 & 1,2 \\
$\mathbf{2 0 0 2}$ & 3,9 & 4,5 & 1,2 \\
$\mathbf{2 0 0 3}$ & 3,5 & 8,8 & 1,2 \\
$\mathbf{2 0 0 4}$ & 4,1 & 7,9 & 1,6 \\
$\mathbf{2 0 0 5}$ & 4,4 & 8,2 & 2,1 \\
$\mathbf{2 0 0 6}$ & 3,1 & 3,7 & 2,3 \\
$\mathbf{2 0 0 7}$ & 3,2 & 3,5 & 2,8 \\
$\mathbf{2 0 0 8}$ & 4,3 & 5 & 1,6 \\
$\mathbf{2 0 0 9}$ & 6,2 & 9,5 & 9,5 \\
$\mathbf{2 0 1 0}$ & 6,2 & 8,2 & 8,2 \\
\hline & Inadequate Conditions; \\
& $\square$ Controlled Conditions; \\
\hline
\end{tabular}


Table 3 - The beach bathing quality of CELIC, based on microbiological indicators of fecal pollution.

Tabela 3 - The beach bathing quality of CELIC, based on microbiological indicators of fecal pollution.

\begin{tabular}{|c|c|c|c|c|c|c|}
\hline \multirow[b]{2}{*}{ Year } & \multicolumn{6}{|c|}{ Iguape } \\
\hline & Optimal & good & regular & poor & very poor & Systematically good \\
\hline 2000 & & 67 & & & & 33 \\
\hline 2001 & & 33 & 67 & & & \\
\hline 2002 & & & & & & 100 \\
\hline 2003 & & & & & & 100 \\
\hline 2004 & & & & & & 100 \\
\hline 2005 & & & & & & 100 \\
\hline 2006 & & & 67 & & & 33 \\
\hline 2007 & & & & & & 100 \\
\hline 2008 & & & & & & 100 \\
\hline 2009 & & & & & & 100 \\
\hline 2010 & & & & & & 100 \\
\hline 2011 & & 50 & & 50 & & \\
\hline
\end{tabular}

\begin{tabular}{|c|c|c|c|c|c|c|}
\hline \multirow[b]{2}{*}{ Year } & \multicolumn{6}{|c|}{ Ilha Comprida } \\
\hline & optimal & good & regular & poor & very poor & Systematically good \\
\hline 2000 & & & & & & 100 \\
\hline 2001 & & & & & & 100 \\
\hline 2002 & & & & & & 100 \\
\hline 2003 & & & 33 & & & 67 \\
\hline 2004 & & & 33 & & & 67 \\
\hline 2005 & & & & & & 100 \\
\hline 2006 & & & 67 & & & 33 \\
\hline 2007 & & & & 33 & & 67 \\
\hline 2008 & & & 33 & & & 67 \\
\hline 2009 & & & 67 & & & 33 \\
\hline 2010 & 34 & & & 33 & & 33 \\
\hline 2011 & 33 & & & & & 67 \\
\hline
\end{tabular}

the CELIC (CETESB, 2010). Thus, the three cities need to cover the costs of transporting and disposing their residues in outer localities because they do not have landfills that meet the necessary requirements. Nevertheless, Cananéia pays to dispose its wastes in a location that is not considered completely appropriate according to the legal state requirements (CETESB, 2010). The National Policy on Solid Residues (Federal Law $\mathrm{n}^{\mathrm{o}} 12.305 / 10$ ) established a goal of doing away with the illegal dumping sites of urban wastes throughout the country by 2014 . However, according to the IBGE (2011), only 33\% of Brazilian cities dispose their domestic residues in appropriate sanitary landfills.

The beach bathing quality (Table 3 ) is determined through an analysis of the amount of bacteria belonging to the group of fecal coliforms or enterococcus, which are found in large amounts in feces and have been used to assess sanitary conditions (CETESB, 2011). Until 2007, three beaches in each city were monitored, but since 2007, Iguape has had only two beaches monitored. Cananéia is not monitored for these parameters, because all of its beaches are located within the Ilha do Cardoso State Park, which is a protected area. Despite limited visitation and primary contact with water (Federal Law $\mathrm{n}^{\circ} 9.985 / 00$ ), it is not yet monitored by the system adopted for the beaches of the São Paulo coast.

Data from Table 4 indicate that Cananéia has experienced a relative deterioration in the sewage collection and treatment services, even though population growth has remained relatively stable. Iguape was found to 
have the worst conditions in terms of the total sewage collected, but this city has experienced improvements in its wastewater treatment system; since 2002, efficiency in treating the collected sewage has increased to $48 \%$ and remained close to this value through the last sampling. Ilha Comprida has evolved the most in these two aspects, but it still has the worst results. The IBGE (2008) data show that the sewage collection and treatment services evolved slightly, increasing from $52.2 \%$ in 2000 to $55.2 \%$ in 2008 , but the cities that already had this service presented an average improvement of $22 \%$. The results indicate that, in the three studied cities, both the collection and the efficiency of wastewater treatment need to be significantly improved.

Among the water-borne diseases that may be related to sanitation conditions, diarrhea exhibited relevant results (figure 5). The recorded number of cases of diarrhea over the last few years has decreased only in Iguape. According to WHO (2009), diarrhea is the second leading cause of death in children under five years of age in developing countries, behind only of pneumonia, and according to Maranhão et al. (2011), this statistic is valid to Brazil.

The most recent results reported for the three municipalities indicated that the cities reduced their child mortality rates overall, in spite of high oscillations and the existence of some gaps in the available data (table 5). Cananéia has a relatively high rate of child mortality compared to the state average, which is 11.86 deaths per thousand live births (SEADE, 2010). The

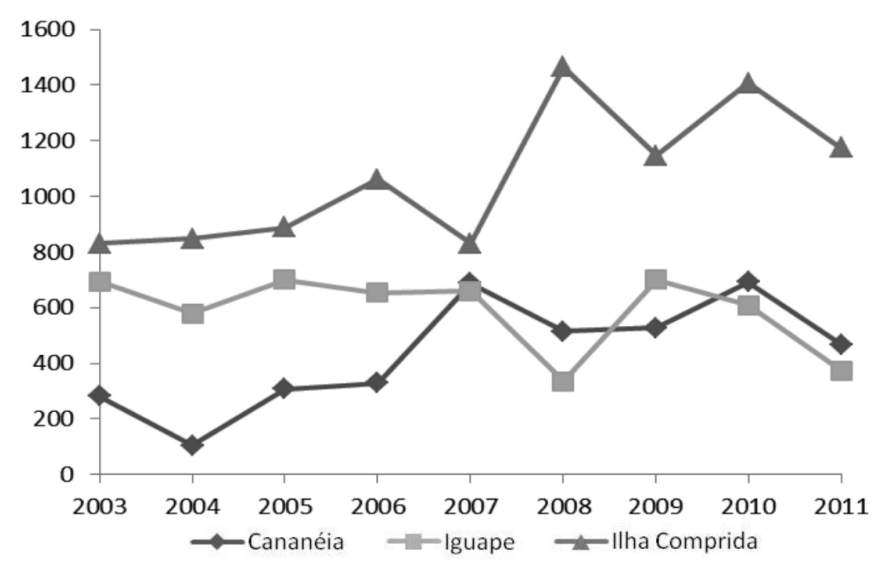

Figure 5 - Number of diarrhea cases in CELIC cities.

Figura 5 - Number of diarrhea cases in CELIC cities.

reduction of child mortality rates is among the Millennium Development Goals (MDGs) established by the United Nations Development Program (UNDP). According to the OMS (2013), this reduction requires a strong effort, since it largely depends on initiatives that can provide access to clean water and basic sanitation, which are the main primary causes of child mortality.

Brazil has a goal to reduce child mortality to at least 17.9 deaths per thousand live births by 2015 (IPEA, 2010), and the CELIC cities achieved that goal. However, when it comes to public health, the ideal goal is to make these rates get as close to zero as possible, and the right of access to basic sanitation should be guaranteed to the entire population.

Table 4: Rates of sewage collection and treatment in CELIC cities.

Table 4: Rates of sewage collection and treatment in CELIC cities.

\begin{tabular}{|c|ccc|ccc|}
\hline \multirow{2}{*}{ Year } & $\begin{array}{c}\text { Proportion of collected sewage in } \\
\text { relation to the total sewage } \\
\text { generated (\%) }\end{array}$ & \multicolumn{3}{|c|}{$\begin{array}{c}\text { Reduction of organic load } \\
\text { pollution (\%) }\end{array}$} \\
\cline { 2 - 7 } & Cananéia & Iguape & $\begin{array}{c}\text { Ilha } \\
\text { Comprida }\end{array}$ & Cananéia & Iguape & $\begin{array}{c}\text { Ilha } \\
\text { Comprida }\end{array}$ \\
$\mathbf{2 0 0 1}$ & 53 & 67 & 13 & 47 & 0 & 11 \\
$\mathbf{2 0 0 2}$ & 53 & 67 & 13 & 47 & 0 & 11 \\
$\mathbf{2 0 0 3}$ & 45 & 60 & 12 & 36 & 48 & 10 \\
$\mathbf{2 0 0 4}$ & 45 & 61 & 15 & 36 & 49 & 13 \\
$\mathbf{2 0 0 5}$ & 45 & 62 & 19 & 36 & 50 & 16 \\
$\mathbf{2 0 0 6}$ & 46 & 59 & 22 & 37 & 48 & 21 \\
$\mathbf{2 0 0 7}$ & 47 & 59 & 25 & 38 & 47 & 20 \\
$\mathbf{2 0 0 8}$ & 49 & 58 & 26 & 60 & 58 & 25 \\
$\mathbf{2 0 0 9}$ & 49 & 58 & 30 & 40 & 50 & 8 \\
$\mathbf{2 0 1 0}$ & 49 & 58 & 30 & 80 & 86 & 25 \\
$\mathbf{2 0 1 1}$ & 49 & 60 & 35 & 38,8 & 51,4 & 33,4 \\
\hline
\end{tabular}


The decrease in child mortality rates may also be related to the increase in GDP, since the increased purchasing power of a population often results in infrastructural improvements to their homes and the consumption of products related to health and hygiene. Such improvements enable the population to reach and experience better sanitary conditions. However, it is evident that GDP evolves much faster than health and sanitation indicators.

Table 5 - Child mortality rates (per thousand live births) in CELIC cities (Source: SEADE Foundation).

Tabela 5 - Child mortality rates (per thousand live births) in CELIC cities (Source: SEADE Foundation).

\begin{tabular}{cccc}
\hline \multirow{2}{*}{ Year } & \multicolumn{3}{c}{ Child mortality rates (per thousand live births) } \\
\cline { 2 - 4 } & Cananéia & Iguape & Ilha Comprida \\
$\mathbf{1 9 9 3}$ & 16,6 & 28,78 & \\
$\mathbf{1 9 9 4}$ & 15,56 & 27,54 & 21,74 \\
$\mathbf{1 9 9 5}$ & 19,38 & 25,82 & \\
$\mathbf{1 9 9 6}$ & 30,04 & 19,08 & 27,4 \\
$\mathbf{1 9 9 7}$ & 41,49 & 15,49 & 44,12 \\
$\mathbf{1 9 9 8}$ & 14,04 & 24,25 & \\
$\mathbf{1 9 9 9}$ & 20,24 & 21,63 & 12,05 \\
$\mathbf{2 0 0 0}$ & 11,67 & 21,91 & 11,11 \\
$\mathbf{2 0 0 1}$ & 20,92 & 22,26 & 22,22 \\
\hline $\mathbf{2 0 0 2}$ & 8,44 & 9,52 & 27,03 \\
\hline $\mathbf{2 0 0 3}$ & 28,57 & 13,67 & 27,03 \\
\hline $\mathbf{2 0 0 4}$ & 9,35 & 9,45 & 9,17 \\
\hline $\mathbf{2 0 0 5}$ & 4,81 & 9,9 & \\
\hline $\mathbf{2 0 0 6}$ & & 13,13 & \\
\hline $\mathbf{2 0 0 7}$ & 19,05 & 16,51 & 17,7 \\
\hline $\mathbf{2 0 0 8}$ & 5,13 & 12,59 & 7,69 \\
\hline $\mathbf{2 0 0 9}$ & 11,11 & 11,99 & \\
\hline $\mathbf{2 0 1 0}$ & 15,87 & 8,26 & 8,33 \\
\hline
\end{tabular}

\subsection{Response}

The pressure indicators demonstrate a growth in economic activities that has not been accompanied by the improvement of sanitation facilities (sewage/wastes). State indicators reveal slow progress and the persistence of an inadequate situation; thus, the analysis of response indicators allows for an evaluation of government actions to improve sanitary conditions and public health, which would be mandatory to the achievement of the coastal management goals.

When it comes to healthcare facilities, although the cities had significantly increased their respective numbers of employees (Table 6), not enough information on the number of hospital beds has been made available (Table 7).

Table 6 - Number of employees in the public healthcare system in CELIC cities.

Tabela 6 - Number of employees in the public healthcare system in CELIC cities.

\begin{tabular}{cccc}
\hline \multirow{2}{*}{ Year } & \multicolumn{3}{c}{$\begin{array}{c}\text { Professionals hired under the public } \\
\text { healthcare system }\end{array}$} \\
\cline { 2 - 4 } $\mathbf{2 0 0 0}$ & 32 & 148 & 15 \\
$\mathbf{2 0 0 1}$ & 40 & 170 & 23 \\
$\mathbf{2 0 0 2}$ & 46 & 189 & 32 \\
$\mathbf{2 0 0 3}$ & 47 & 191 & 30 \\
$\mathbf{2 0 0 4}$ & 52 & 193 & 31 \\
$\mathbf{2 0 0 5}$ & 56 & 197 & 37 \\
$\mathbf{2 0 0 6}$ & 60 & 215 & 45 \\
$\mathbf{2 0 0 7}$ & 60 & 210 & 52 \\
\hline $\mathbf{2 0 0 8}$ & 76 & 236 & 64 \\
\hline $\mathbf{2 0 0 9}$ & 85 & 259 & 63 \\
\hline $\mathbf{2 0 1 0}$ & 78 & 248 & 75 \\
\hline
\end{tabular}

The number of hospital beds is commonly used in Brazil as an indicator of progress in investment in the public healthcare system. This is a relevant lack of official information that prevents a proper analysis of the actions taken to solve this issue. Cananéia has presented no data since 2003, and Ilha Comprida has not presented any data since the beginning of the sampling period, which can portray either the lack of hospital beds in this city or simply the lack of data collection. In the case of Cananéia, there has been a dramatic decrease in the number of hospital beds, and the coefficient of hospital beds from the public healthcare system (SUS) per thousand inhabitants is much lower than the amount recommended by the Brazilian Ministry of Health, which is between 2.5 and 3.0 beds per thousand residents (Federal Law $n^{\circ} 1101 / \mathrm{GM}$ ). Thus, it can be inferred that the population of these municipalities have been underserved in relation to their right to access to health care, which is guaranteed by the Federal Constitution (1988).

These data show that there are no effective responses by the government in terms of investments in healthcare, which should be given in order to keep up with or anticipate population increases in the region (Iguape and Ilha Comprida). In addition, there has been an increase in the number of cases of diarrhea, which indicates unsuitable conditions and may have a relationship to the low percentages of sewage collection and treatment. At the same time, though child mortality rates have dropped, the values are still relatively high, and the 
Table 7 - Structure of hospital admission into public healthcare services (number of public hospital beds) in CELIC cities. Tabela 7 - Structure of hospital admission into public healthcare services (number of public hospital beds) in CELIC cities.

\begin{tabular}{|c|c|c|c|c|c|c|}
\hline \multirow{2}{*}{ Year } & \multicolumn{3}{|c|}{ Number of hospital beds } & \multicolumn{3}{|c|}{ SUS beds (per thousand inhabitants) } \\
\hline & Cananéia & Iguape & Ilha Comprida & Cananéia & Iguape & Ilha Comprida \\
\hline 1995 & 17 & 85 & & 1,17 & 3,28 & \\
\hline 1996 & 17 & 85 & & 1,17 & 3,26 & \\
\hline 1997 & 17 & 85 & & 1,78 & 3,26 & \\
\hline 1998 & 17 & 85 & & 1,78 & 3,25 & \\
\hline 1999 & 17 & 35 & & 1,44 & 1,29 & \\
\hline 2000 & 17 & 35 & & 1,4 & 1,28 & \\
\hline 2001 & 17 & 85 & & 1,38 & 3,07 & \\
\hline 2002 & 17 & 35 & & 1,38 & 1,26 & \\
\hline 2003 & 17 & 35 & & 1,38 & 1,25 & \\
\hline \multicolumn{7}{|l|}{2004} \\
\hline 2005 & & 34 & & 1,14 & 1,2 & \\
\hline 2006 & & 34 & & & 1,19 & \\
\hline 2007 & & 34 & & & 1,19 & \\
\hline 2008 & & 34 & & & 1,18 & \\
\hline 2009 & & 34 & & & 1,18 & \\
\hline 2010 & & 34 & & & 1,18 & \\
\hline 2011 & & 34 & & & 1,18 & \\
\hline
\end{tabular}

number of hospital beds is not increasing in proportion to the population growth, nor has it increased proportionally to the increase in the area's cases of diarrhea. The lack of public hospital beds forces the CELIC population to seek out the private healthcare system and pay for those services, and it also leads to overflow into hospitals in the neighboring cities, as their respective healthcare services are demanded to care for patients from CELIC locations.

There are not enough data available regarding basic sanitation in this region, and the coverage of sewage service is small (Table 8). Iguape, which provides the best service, has only $57.62 \%$ households reached by this service, which is well below the state average of $82 \%$ service (IBGE, 2008). The data on water supply in the region (Table 8 ) are relatively high and are between $77.76 \%$ (Cananéia) and 82.32\% (Ilha Comprida). However, it was also noted that there was scarce evolution of this service, and the values are still below average for the Brazilian southeast region, which is $87.5 \%$ (IBGE, 2008).

In addition to the lack of data on sanitation, these data often conflict with each other; in other words, it is possible to find different values in different databases dealing with the same variable. For example: the data on basic sanitation, generated by the public water company (SABESP) and those available in the reports from the local Geographical Information System of Ribeira
(Sistema de Informações Geográficas do Ribeira - SIGRB) are different from those generated by National System of Sanitation Information (Sistema Nacional de Informações Sanitárias - SNIS).

\section{Conclusions}

When it comes to sanitary conditions, the CELIC is in a situation in which the pressures exerted on environmental issues are relatively mild but exhibit an increasing pattern. State indicators show that there is a lack of structure in terms of basic needs such as health and sanitation. Though the pressures in the current situation have not reached large-scale values, they may have already had relevant impacts to the environment and public health. Although economic factors have evolved considerably, the current lack of both sanitation and healthcare system infrastructure reflects the insufficiency of these public services, which, in turn, shows that the economic gains obtained are not efficiently turned into improvements in health and sanitation systems by the government. The public sector has also failed to produced consistent and organized responses to this problem; on the contrary, it tends to consider such constitutional obligations as superfluous. This problem is worsened by the weakness or complete lack of reliable data that can be obtained over the long term, despite the coastal management plan theoretically predicts some tools that are not performed by the govern 
Table 8 - Index of households served by sanitary systems (water supply and sewage collection) in CELIC cities.

Tabela 8 - Index of households served by sanitary systems (water supply and sewage collection) in CELIC cities.

\begin{tabular}{|c|c|c|c|c|c|c|}
\hline \multirow{2}{*}{ Year } & \multicolumn{3}{|c|}{ Water Supply Service (\%) } & \multicolumn{3}{|c|}{ Sewage Collection Service (\%) } \\
\hline & Cananéia & Iguape & $\begin{array}{c}\text { Ilha } \\
\text { Comprida }\end{array}$ & Cananéia & Iguape & $\begin{array}{c}\text { Ilha } \\
\text { Comprida }\end{array}$ \\
\hline 2003 & & 73,45 & & & & \\
\hline 2004 & 72,44 & 71,75 & & 41,35 & 54,66 & \\
\hline 2005 & 71,68 & 71,24 & & 43,45 & 54,87 & \\
\hline 2006 & 72,22 & 70,87 & 86,49 & 44,28 & 54,93 & 23,46 \\
\hline 2007 & 85,94 & 70,28 & 98,95 & & & \\
\hline 2008 & 85,48 & 67,49 & 95,21 & 44,97 & 56,78 & 28,35 \\
\hline 2009 & 86,53 & 67,23 & 96,69 & 44,46 & 57,11 & 30,4 \\
\hline 2010 & 77,76 & 71,53 & 82,32 & 44,92 & 57,62 & 31,89 \\
\hline
\end{tabular}

ment, as the annual Environmental Quality Reports and the Action Plans.

The consequence of this management of the CELIC is that the basic sanitation structure and system are insufficient, and actions taken are not consistent with local demand. In spite of the local conditions (a low population, the presence of protected areas, and the concentration of the population in urban areas), which should facilitate the planning and management of sanitation

\section{References}

Carvalho, P.G.M.; Barcellos, F.C. (2009) - Políticas públicas e sustentabilidade ambiental. Construindo indicadores de sustentabilidade. Indicadores Econômicos FEE (ISSN: 01033905), 37(1):s/p, Fundação de Economia e Estatística Siegfried Emanuel Heuser, Porto Alegre, RS, Brazil. Available on-line at http://revistas.fee.tche.br/index.php/indicadores/article/view/2280/2656

Cavalcanti, C. (2004) - Uma Tentativa de Caracterização da Economia Ecológica. Ambiente \& Sociedade, 7(1):149-156. DOI: $10.1590 / \mathrm{S} 1414-753 X 2004000100009$

Chaves, H.M.L.; Alipaz, S. (2007) - An Integrated Indicator Based on Basin Hydrology, Environment, Life, and Policy: The Watershed Sustainability Index. Water Resource Management, 21(5):883 - 895. DOI: 10.1007/s11269-006-9107-2

Cicin-Sain, B.; Knecht, R.W. (1998) - Integrated coastal and ocean management: concepts and pratices. $517 \mathrm{p}$., Island Press Washington, D.C. U.S.A. ISBN: 1559636041.

SIG-RB (2012) - Relatório de Situação dos Recursos Hídricos da Unidade de Gerenciamento $n^{\circ} 11.98 \mathrm{p}$., Sistema de Informações Geográficas do Ribeira de Iguape e Litoral Sul (SIG-RB), Comitê da Bacia Hidrográfica do Ribeira de Iguape e Litoral Sul, Registro, SP, Brasil. Available on-line at http://www.sigrb.com.br/projetos /consulta.php?id=5

CETESB (2010) - Inventário Estadual de Resíduos Sólidos Domiciliares. - 2010. 186p., Companhia Ambiental do Estado de São Paulo (CETESB), São Paulo, SP, Brasil. Available on-line at http://www.cetesb.sp.gov.br/userfiles/file/residuos-solidos/residuos Solidos2010.zip measures, the pressures seem to increase, resulting in a state with a serious lack of infrastructure. For seemingly political reasons, there have not been enough actions taken that seek to mitigate or resolve this scenario. Therefore, it is necessary that government management of the CELIC take sanitation and public health into account so that the economic gains can effectively translate into improvements in quality of life and environment.

CETESB (2010) - Balneabilidade das Praias Paulistas - 2010. 257p., Companhia Ambiental do Estado de São Paulo (CETESB), São Paulo, SP, Brasil. Available on-line at http://www.cetesb.sp.gov.br/Agua/relatorios/praias/relatorio_balneabilid ade_2010.zip

CETESB (2011) - Balneabilidade das Praias Paulistas - 2011. 342p., Companhia Ambiental do Estado de São Paulo (CETESB), São Paulo, SP, Brasil. Available on-line at http://www.cetesb.sp.gov.br/userfiles/file/agua/praias/relatorios/relatorio _balneabilidade_2011.zip

Freitas, M.A.P. (2005) - Zona Costeira e Meio Ambiente - Aspectos Jurídicos. 232p., Juruá Editora, Curitiba, PR, Brasil. ISBN: 853620972-0.

SEADE (2010) - São Paulo: Objetivos de Desenvolvimento do Milênio. Relatório Estadual de Acompanhamento. 63p., Fundação Sistema Estadual de Análise de Dados (SEADE), Secretaria de Planejamento e Desenvolvimento Regional, São Paulo, SP, Brasil. Available on-line at http://www.seade.gov.br /produtos/odm/pdf/ODM_2010_publicacao_completa.pdf

IBGE (2008) - Pesquisa Nacional de Saneamento Básico 2008. 219p., Instituto Brasileiro de Geografia e Estatística (IBGE), Rio de Janeiro, RJ, Brasil. ISBN: 978-8524041358. Available online at http://www.ibge.gov.br/home/estatistica/populacao/condicao devida/pnsb2008/PNSB_2008.pdf

IBGE (2011) - Atlas Nacional de Saneamento Básico 2011. 268p., Instituto Brasileiro de Geografia e Estatística (IBGE), Rio de Janeiro, RJ, Brasil. ISBN: 978-85-240-4202-7. Available on-line 
at ftp://geoftp.ibge.gov.br/atlas/atlas_saneamento/atlas_saneamento_ 2011.zip

Ipea (2010) - Objetivos de Desenvolvimento do Milênio - Relatório Nacional de Acompanhamento 2010. 184p., Instituto de Pesquisa Econômica Aplicada (Ipea), Ministério do Planejamento, Orçamento e Gestão, Secretaria de Planejamento e Investimentos Estratégicos, Brasília, DF, Brasil. ISBN: 857811043-9. Available on-line at http://www.ipea.gov.br/portal /index.php?option $=$ com_content $\&$ view $=$ article $\&$ id $=1061 \&$ Itemid $=9$

Jablonski, S.; Filet, M. (2008) - Coastal management in Brazil - A political riddle. Ocean \& Coastal Management, 51(7):536-543. DOI: 10.1016/j.ocecoaman.2008.06.008

Maranhão, A.G.K.; Vasconcelos, A.M.N.; Porto, D.L.; França, E. (2011) - Mortalidade infantil no Brasil: tendências, componentes e causas de morte no período de 2000 a 2010. 20p., Secretaria de Vigilância em Saúde, Brasíla, DF, Brasil. Available on-line at http://repositorio.unb.br/bitstream/10482/12478/1/ CAPITULO_MortalidadeInfantilBrasil.pdf

Marotta, H.; Santos, R.O.; Enrich-Prast, A. (2008) - Monitoramento liminológico: um instrumento para a conservação dos recursos hídricos no planejamento e na gestão urbano-ambientais. Ambiente \& Sociedade, 11(1):67-79. DOI: 10.1590/S1414753X2008000100006

Moraes, A.C.R. (2007) - Contribuições para a gestão costeira no Brasil: elementos para uma geografia do litoral brasileiro. 232p., Annablume, São Paulo, SP, Brasil. ISBN: 9788574196770 .

ONU (1992 [1995]) - Agenda 21. Conferência das Nações Unidas sobre o Meio Ambiente e Desenvolvimento. 472p., Tradução do Ministério das Relações Exteriores com a colaboração do Programa das Nações Unidas para o Meio Ambiente (PNUMA). Câmara dos Deputados, Brasília, DF, Brasil. Available on-line at http://www.onu.org.br/rio20/img/2012/01/agenda21.pdf

OMS (2013) - Estadísticas Sanitarias Mundiales. 172p., Organización Mundial de la Salud (OMS), Genebra, Suíça. ISBN: 9789243564586. Available on-line at http://apps.who.int/ iris/bitstream/10665/82218/1/9789243564586 spa.pdf?ua=1

OECD (1993) - OECD Core Set of Indicators for Environmental Performance Reviews. A synthesis report by the Group on the State of the Environment. 39p., Organisation for Economic Cooperation and Development (OECD), Paris, France. Available online at http://www.fao.org/ag/againfo/programmes/pt/lead/toolbox /Refer/gd93179.pdf

Scherer, M.E.G.; Sanches, M.; Negreiros, D.H. (2009) Gestão das Zonas Costeiras e as Políticas Públicas no Brasil: um diagnóstico. In: Juan Manuel Barragan Muñoz (Coord.), Manejo Costero Integrado y Política Pública en Iberoamérica: Un diagnóstico. Necesidad de Cambio, pp. 291-330, Red Ibermar (CYTED), Cádiz, Espanha. ISBN: 978-8469303559. Available on-line at http://hum117.uca.es/HUM117/ibermar/Resultados y descargas/publicaciones/brasil

Stiglitz, J.E.; Sen, A.; Fitoussi, J.P. (coord.) (2009) - Report by the Commission on the Measurement of Economic Performance and Social Progress. 291p., Commission on the Measurement of Economic Performance and Social Progress, Paris, France. Available on-line at http://www.stiglitz-sen-fitoussi.fr/ documents/rapport_anglais.pdf
WHO (2009) - Diarrhoea: Why Children Are Still Dying and What Can Be Done. 68p., United Nations Children's Fund (UNICEF)/World Health Organization (WHO), New York, NY, U.S.A. ISBN: 978-9280644623. Available on-line at http://www.unicef.org/media/files/Final_Diarrhoea_Report_October_20 09_final.pdf

Tsalik, S.; Schiffrin, A. (org.) (2005) - Reportando o petróleo: Um Guia Jornalístico sobre Energia e Desenvolvimento. 170p., Open Society Institute, New York, NY, U.S.A. Available on-line at http://archive.revenuewatch.org/reports/072305po.pdf

UNEP (2006) - Marine and coastal ecosystems and human wellbeing: A synthesis report based on the findings of the Millennium Ecosystem Assessment. 76p., United Nation Environment Programme (UNEP), Nairobi, Kenya. Available online at http://www.unep.org/pdf/Completev6_LR.pdf

\section{Legislation}

1988 - Constituição da República Federativa do Brasil. Publicado no DOU DE 05/10/1988. Available on-line at http://www. planalto.gov.br/ccivil_03/Constituicao/Constituicao.htm.

1988 - Lei Estadual $n^{\circ}$ 10.019/88 - Dispõe sobre o Plano Estadual de Gerenciamento Costeiro, e dá outras providências. Available online at http://www.jusbrasil.com.br/diarios/68889145/dosp-legislativo10-04-2014-pg-26

1988 - Lei Federal $n^{\circ}$ 7.661/88 - Institui o Plano Nacional de Gerenciamento Costeiro e dá outras providências. Publicado no D.O.U. de 18.5.1998. Available on-line at http://www.planalto .gov.br/ccivil_03/leis/17661.htm.

2000 - Lei Federal $n$ 9.985/00 - Regulamenta o art. 225, § 1o, incisos I, II, III e VII da Constituição Federal, institui o Sistema Nacional de Unidades de Conservação da Natureza e dá outras providências. Publicado no D.O.U. de 19.7.2000. Available online at http://www.planalto.gov.br/ccivil_03/leis/19985.htm

2002 - Portaria ${ }^{\circ}{ }^{\circ}$ 1101/GM (12 de junho de 2002). Ministério da Saúde, Brasil, DF. 2002. Available on-line at http://www.saude. mg.gov.br/images/documentos/PORTARIA_1101.pdf

2010 - Lei Federal $n^{\circ}$ 12.305/10 - Institui a Política Nacional de Resíduos Sólidos; altera a Lei $n^{\circ} 9.605$, de 12 de fevereiro de 1998; e dá outras providências. Publicado no DOU de 3.8.2010. Available on-line at http://www.planalto.gov.br/ccivil_03/_ato20072010/2010/lei/112305.htm.

\section{Internet web-pages}

CVE (s/d) - Dados Estatísticos. Centro de Vigilância Epidemológica (CVE), São Paulo, SP, Brasil. http://www.cve. saude.sp.gov.br/htm/hidrica/hidri_estat.html

IBGE (s/d) - Banco de Dados. Cidades. Instituto Brasileiro de Geografia e Estatística (IBGE), Rio de Janeiro, RJ, Brasil. http://www.ibge.gov.br/cidadesat/index.php

SNIS (s/d) - Banco de Dados. Sistema Nacional de Informações sobre Saneamento (SNIS), Brasília, DF, Brasil. http://www.snis. gov.br/PaginaCarrega.php?EWRErterterTERTer=29 